\title{
Non-thermal plasma modified growth and physiology in Triticum aestivum via generated signaling molecules and $\mathrm{UV}$ radiation
}

\author{
A. IRANBAKHSH ${ }^{1 *}$, M. GHORANNEVISS ${ }^{2}$ Z. ORAGHI ARDEBILI ${ }^{3}$, N. ORAGHI ARDEBILI ${ }^{4}$, \\ S. HESAMI TACKALLOU ${ }^{5}$, and H. NIKMARAM ${ }^{2}$
}

Department of Biology ${ }^{1}$ and Plasma Physics Research Center ${ }^{2}$, Science and Research Branch, Islamic Azad University, Tehran, 1477893855, Iran

Department of Biology, Garmsar Branch, Islamic Azad University, Garmsar, 3581755796, Iran ${ }^{3}$

Department of Biology, Islamshahr Branch, Islamic Azad University, Islamshahr, 3314767653, Iran ${ }^{4}$ Department of Biology, Tehran Central Branch, Islamic Azad University, Tehran, 1667846511, Iran ${ }^{5}$

\begin{abstract}
The current research was carried out to reveal the possible impacts of cold plasma on growth and physiology of wheat, as a new approach in plant science. Short and long-term impacts of different types of plasma (nitrogen and helium) with surface power density of $0.4 \mathrm{~W} \mathrm{~cm}^{-2}$, exposure times $(15,30,60$, and $120 \mathrm{~s})$, and repetitions (1,2, and 4 times with $24 \mathrm{~h}$ intervals) were evaluated. Single-time applied helium or nitrogen derived plasma significantly promoted total root and shoot lengths, in contrast to four times application, and the root system was more sensitive than the shoot one. In addition, seedlings were more sensitive to nitrogen derived plasma, compared with helium. The physiological responses to plasma treatment were analyzed via protein assay and peroxidase or phenylalanine ammonia lyase (PAL) activities measurements. Plasma generated signaling molecules, especially ozone, nitric oxide, and/or UV radiation induced promotions in the peroxidase and PAL activities as well as increase in protein content in leaves, especially when times and/or repetitions increased. Plants were perished by the nitrogen derived plasma at the highest exposure time and number of repetitions. However, the seedlings with inhibited growth not only caught up control one month after, but even the growth rate and biomass accumulation in the shoot and leaves were accelerated. Increased leaf soluble phenol content was recorded in plasma treated seedlings, especially at longer times and more repetitions.
\end{abstract}

Additional key words: cold plasma, helium, nitrogen, nitric oxide, ozone, phenylalanine ammonia lyase, peroxidase, proteins, wheat.

\section{Introduction}

Cold (non-thermal) atmospheric pressure plasmas are emerging as a novel tool for the treatment of living tissues for biological and medical purposes (Alekseev et al. 2014). Non-thermal dielectric barrier discharge plasma (DBD) is one of well-developed methods of plasma generating, and it is called cold because it is a non-thermal discharge produced by establishing strong electrical fields across small gap fills with nonconducting coat that prevents the transition of the plasma discharge into an arc and heat production (Louste et al. 2005). It is usually working at atmospheric pressure and normally obtained between two parallel electrodes made from materials of low dielectric loss and high breakdown

strength (glass, quartz, polymer, or ceramics) separated by a gap of some millimeters and excited by alternating current voltage with frequency in the range of $1-20 \mathrm{kHz}$ (Shi and Kong 2005).

Nitric oxide, hydrogen peroxide, superoxide, singlet oxygen, electrons, positive ions, and UV radiation are generated in DBD (Bußler et al. 2015a). These compounds, especially ozone and nitric oxide as biologically noteworthy active compounds, as well as UV radiation, could act as effective elicitor to modify plant growth, development, and metabolism. The synthesis of nitric oxide from air, aiming plasma technology is according to a really well-known reaction between $\mathrm{N}_{2}$

Submitted 3 April 2016, last revision 3 November 2016, accepted 4 November 2016.

Abbreviations: DBD - dielectric barrier discharge plasma; PAL - phenylalanine ammonia lyase.

Acknowledgements: Authors would like to thank Mahsid Saberi, Mahdi Ali-Arab, Dorsa Khaksari, Reyhane Moosaie Daryan, Zeinab Jahanbakhsh, Seyede Sepideh Mirmohammad-Hosseini Ooshani, and Maryam Amini for their benevolent collaborations in the research procedure. The corresponding author specially would like to acknowledge the Plasma Physics Research Center, Science and Research Branch, Islamic Azad University, Tehran, Iran.

* Corresponding author; fax: (+98) 2144845120, e-mail: iranbakhsh@iau.ac.ir 
and $\mathrm{O}_{2}$ in the air activated by plasma (Fridman 2008). Nitric oxide acts as a signaling molecule at different steps of the plant life cycle (Lamattina and Polacco 2007, Domingos et al. 2015, Kashyap et al. 2015, Santisree et al. 2015).

The cold plasma treatment has been introduced as a fast, economic, and pollution-free method to reduce the bacterial bearing rate of seeds (Mitra et al. 2014), to alter seed coat structure, to enhance the permeability of seed coat, to promote seed germination and seedling growth (Sera et al. 2008, 2010, Filatova et al. 2011, Chen et al. 2012, Park et al. 2013, Ling et al. 2014, Mihai et al. 2014, Stolárik et al. 2015), and to modify some physiological characteristics (Wu et al. 2007, Ling et al. 2014, Stolárik et al. 2015) and yield (Jiang et al. 2014). Data about plant-plasma interaction are rare, so more convincing studies are needed to clarify the underlying mechanisms involved in the above mentioned effects.

Wheat is consumed as staple cereal in many countries, making more than a third of earth's population, so improvement in its agricultural properties could elevate life safety levels and strengthen stability for development (Welch and Graham 2004). There are many interests to achieve eco-friendly suitable ways to trigger plant growth and improve plant resistance to stress conditions. There are not many studies about the affordable range of plasma treatment and possible effects of cold plasma on the various aspects of plant differentiation, growth, development and physiology. The current research was carried out to evaluate the possible impacts of different application modes of cold plasma on the plant growth and physiology in wheat.

\section{Materials and methods}

Seeds of wheat (Triticum aestivum L. cv. Parsi) were purchased from the Seed and Plant Improvement Institute, Karaj, Iran.

Dielectric barrier discharge (DBD) plasma was generated at atmospheric pressure between two glass plates $(190 \times 190 \times 3 \mathrm{~mm})$ as dielectric barriers covering the two powered circular plate copper electrodes (diameter $180 \mathrm{~mm}$ ) (Fig. 1). The gap between dielectrics was $4 \mathrm{~mm}$. Nitrogen and helium were applied as the functional gas between dielectrics. The dielectric acts as a stabilizing material when the potential across the gap reaches the breakdown voltage leading to the formation of a large number of micro-discharges. To generate DBD plasma, a modified alternative current (AC) high voltage power supply (mp516, Nik Plasma Tech., Iran) was used. Applied voltage was measured by a high voltage probe (HVP40, Pintek Electronics, Taiwan) connected to an oscilloscope (TDS1012B, Tektronix, USA). During all experiments, the frequency and the applied voltage of the device was fixed at $20 \mathrm{kHz}$ and $15 \mathrm{kV}$, respectively. The instrument power was $100 \mathrm{~W}$, so for $254.3 \mathrm{~cm}^{2}$ plasma treatment areas, the surface power density was equal to $0.4 \mathrm{~W} \mathrm{~cm}^{-2}$.

Wheat seeds were exposed to the plasma discharge in gases pressure of $100 \mathrm{~Pa}$. Meanwhile, the control samples were left untreated. Briefly, the seeds ( $24 \mathrm{~h}$ after soaking) were treated with two kinds of plasma, helium or nitrogen in five different times of exposure $(0,15,30,60$, and $120 \mathrm{~s})$ with three repetition modes $(1,2$, or 4 times with $24 \mathrm{~h}$ intervals). Treatment groups were called on the basis of plasma type, time of exposure, and repetition times as follows: C (control), N15-1 (N plasma, 15 s once), N30-1 (N plasma, $30 \mathrm{~s}$ once), N60-1 (N plasma, $60 \mathrm{~s}$ once), N120-1 (N plasma, $120 \mathrm{~s}$ once), N15-2 (N plasma, $15 \mathrm{~s}$ twice), and so on, and similarly He15-1 (He plasma, $15 \mathrm{~s}$ once), etc.

The experimental design was completely randomized with four replications. All seeds were grown in Petri dishes of $10 \mathrm{~cm}$ diameter, containing Whatman papers

moistened with distilled water. All samples were kept in a culture room under a 16-h photoperiod, an irradiance of $33.75 \mu$ mol(photon) $\mathrm{m}^{-2} \mathrm{~s}^{-1}$ (fluorescent lamps), a temperature of $25 \pm 3{ }^{\circ} \mathrm{C}$, and an air humidity of $47 \%$. One day after the last plasma treatments, 5-d-old seedlings were planted in $5 \mathrm{~cm}$ pots filled with $200 \mathrm{~g}$ of peat and Perlite (1:1). Evaluations were conducted on 5-d-old seedlings (just one day after the last treatment) and 35-d-old plants (30 d after the last treatments).

Digital images of control and plasma treated seedlings were obtained using a digital camera CANON G12, and total root length (summation of all root lengths of each seedling) and shoot length were analyzed using the ImageJ software, a public domain Java-based image processing program. Shoot and leaf fresh mass were determined in 35-d-old seedlings.

To evaluate the fast reactions, enzymatic activities and protein content were done on samples of 5-d-old seedlings and total soluble phenol content was analyzed in 35-d-old seedlings. Enzymes were extracted at $4{ }^{\circ} \mathrm{C}$ using $0.1 \mathrm{M}$ phosphate buffer ( $\mathrm{pH}$ 7.5), containing $0.5 \mathrm{mM} \mathrm{Na} \mathrm{Na}_{2}$-EDTA and $0.5 \mathrm{mM}$ ascorbic acid. The homogenates were centrifuged at $4{ }^{\circ} \mathrm{C}$ for $15 \mathrm{~min}$ and the supernatant was used for further assays. Protein content was measured according to the method described by Bradford (1976) with bovine serum albumine as a standard. Peroxidase activity was assayed as described by Biles and Abeles (1991). The reaction mixture consisted of acetate buffer $(0.2 \mathrm{M}, \mathrm{pH} 4.8), 3 \%(\mathrm{v} / \mathrm{v}) \mathrm{H}_{2} \mathrm{O}_{2}$, and $0.04 \mathrm{M}$ benzidine in $50 \%(\mathrm{v} / \mathrm{v})$ methanol. The reaction was started by adding the enzyme extract. The absorbance (A) was measured at $530 \mathrm{~nm}$ using spectrophotometer (UV-1700, Shimadzu, Japan). The peroxidase activity was expressed as $\Delta \mathrm{A} \mathrm{g}^{-1}$ (f.m.) $\mathrm{min}^{-1}$. The phenylalanine ammonia lyase (PAL) activity was measured according to the method described by Beaudoin-Eagan and Thorpe (1985). The reaction mixture consisted of $6 \mu \mathrm{M}$ phenylalanine, Tris- $\mathrm{HCl}$ buffer $(0.5 \mathrm{M}, \mathrm{pH} 8)$, and $0.2 \mathrm{~cm}^{3}$ of enzyme extract. 
After $60 \mathrm{~min}$ at $37^{\circ} \mathrm{C}$, the reaction was ended by adding $0.05 \mathrm{~cm}^{3}$ of $5 \mathrm{M} \mathrm{HCl}$ and A was measured at $290 \mathrm{~nm}$. PAL activity was determined by measuring the amount of cinnamic acid produced and expressed in $\mu \mathrm{g}$ (cinnamate) $\mathrm{g}^{-1}$ (f.m.) $\mathrm{min}^{-1}$. Total soluble phenolics in the leaf ethanolic extracts were assessed using the FolinCiocalteu reagent procedure (Goldwasser et al. 1999).
Tannic acid was used as a standard.

Data was analyzed by analysis of variance (ANOVA) as a factorial experiment in a completely randomized design with four replications using SPSS software. Mean separation was performed with Duncan's multiple range test at $P<0.05$.

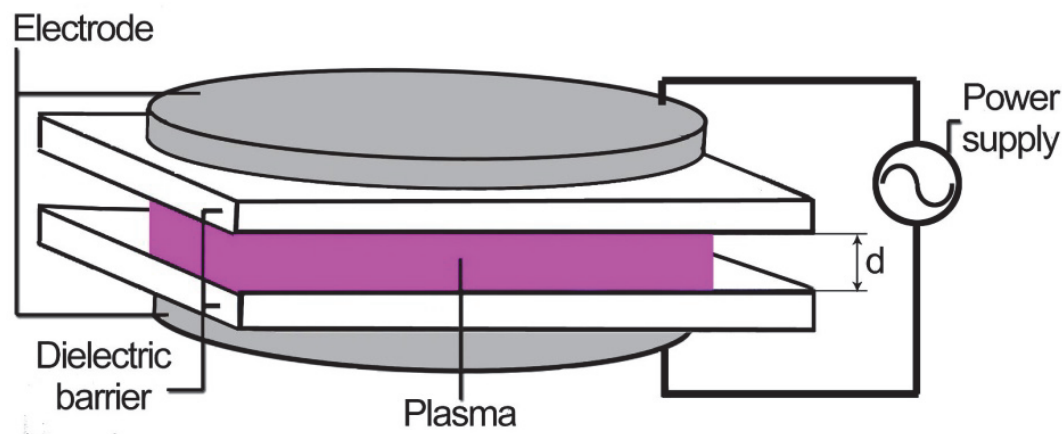

Fig. 1. An apparatus for development of dielectric barrier discharge plasma at atmospheric pressure. Glass dielectric barrier (white) covering two powered circular plate copper electrodes (grey); $\mathrm{d}$ is gap between dielectrics and equal to $4 \mathrm{~mm}$.

\section{Results and discussion}

The single-time He treatments had a meaningful promoting effect on the total root length, but when $\mathrm{He}$ plasma was applied for longer times and/or in more repetitions (He120-4 and He60-4), it reduced the total length of root system meaningfully, in comparison with control (Table 1) and the seedlings showed signs of yellowness and apparent defects. In contrast, treatments of N120-1, N60-1, N30-2, and N30-1 promoted root system elongation (Table 1). Four-time $\mathrm{N}$ plasma treatments resulted in the significant decreases in shoot length, whereas single-time treatments increased shoot length and N60-1, He60-1, and N120-1 induced the highest shoot length (Table 1). The obtained results showed that plasma affected root system more severely than shoots (Fig. 2) and this could be due to higher sensitivity of root meristem cells comparing with shoot meristem. The plant growth reactions to plasma treatments were dependent on times and repetitions, where the growth inhibitory symptoms and defects were clearly recorded in samples exposed for longer times and more repetitions, in contrast to single time treatments. The detrimental impacts of N-plasma were more severe

Table 1. Effects of He or $\mathrm{N}$ derived cold plasma used for different times and repetitions on the total root and shoot lengths in 5-d-old wheat seedlings ( $1 \mathrm{~d}$ after the last treatments). C - control, P15-1 - plasma $15 \mathrm{~s}$ once, P30-1 - plasma $30 \mathrm{~s}$ once, etc. .... P120-4 plasma 120 s four times. Means \pm SEs, $n=4$; values followed by different letters are significantly different at $P \leq 0.05$ according to Duncan's multiple range test.

\begin{tabular}{lccll}
\hline $\begin{array}{l}\text { Parameters } \\
\text { Treatments }\end{array}$ & $\begin{array}{l}\text { Total root length }[\mathrm{mm}] \\
\mathrm{He}\end{array}$ & $\mathrm{N}$ & $\begin{array}{l}\text { Shoot length }[\mathrm{mm}] \\
\text { He }\end{array}$ & $\mathrm{N}$ \\
\hline $\mathrm{C}$ & $53.33 \pm 2.06^{\mathrm{e}}$ & $53.33 \pm 2.06^{\mathrm{f}}$ & $44.78 \pm 0.94^{\mathrm{c}}$ & $44.78 \pm 0.94^{\mathrm{cd}}$ \\
P15-1 & $79.88 \pm 3.56^{\mathrm{c}}$ & $71.60 \pm 2.62^{\mathrm{de}}$ & $48.23 \pm 0.79^{\mathrm{b}}$ & $46.60 \pm 0.75^{\mathrm{bc}}$ \\
P15-2 & $64.24 \pm 1.83^{\mathrm{d}}$ & $74.89 \pm 1.18^{\mathrm{d}}$ & $43.63 \pm 1.84^{\mathrm{cd}}$ & $45.58 \pm 0.46^{\mathrm{bc}}$ \\
P15-4 & $41.61 \pm 1.85^{\mathrm{f}}$ & $51.07 \pm 1.62^{\mathrm{f}}$ & $34.72 \pm 0.86^{\mathrm{f}}$ & $30.83 \pm 0.82^{\mathrm{f}}$ \\
P30-1 & $100.61 \pm 3.10^{\mathrm{b}}$ & $66.05 \pm 1.0^{\mathrm{e}}$ & $48.58 \pm 0.77^{\mathrm{b}}$ & $42.58 \pm 0.42^{\mathrm{de}}$ \\
P30-2 & $67.70 \pm 2.40^{\mathrm{d}}$ & $87.54 \pm 2.72^{\mathrm{c}}$ & $42.78 \pm 1.28^{\mathrm{cde}}$ & $47.38 \pm 0.41^{\mathrm{b}}$ \\
P30-4 & $52.23 \pm 2.42^{\mathrm{e}}$ & $49.49 \pm 1.28^{\mathrm{f}}$ & $35.68 \pm 1.27^{\mathrm{f}}$ & $32.15 \pm 1.57^{\mathrm{f}}$ \\
P60-1 & $116.40 \pm 2.30^{\mathrm{a}}$ & $99.91 \pm 1.75^{\mathrm{b}}$ & $54.63 \pm 0.68^{\mathrm{a}}$ & $53.31 \pm 0.51^{\mathrm{a}}$ \\
P60-2 & $38.40 \pm 3.05^{\mathrm{f}}$ & $70.65 \pm 2.98^{\mathrm{de}}$ & $41.30 \pm 1.18^{\mathrm{de}}$ & $40.68 \pm 1.027^{\mathrm{e}}$ \\
P60-4 & $26.63 \pm 4.36^{\mathrm{g}}$ & $30.78 \pm 3.64^{\mathrm{g}}$ & $30.58 \pm 0.86^{\mathrm{g}}$ & $33.00 \pm 0.74^{\mathrm{f}}$ \\
P120-1 & $121.09 \pm 3.62^{\mathrm{a}}$ & $112.23 \pm 4.82^{\mathrm{a}}$ & $50.71 \pm 0.26^{\mathrm{b}}$ & $51.99 \pm 0.41^{\mathrm{a}}$ \\
P120-2 & $45.32 \pm 2.28^{\mathrm{ef}}$ & $53.49 \pm 1.97^{\mathrm{f}}$ & $40.27 \pm 0.78^{\mathrm{e}}$ & $46.09 \pm 0.90^{\mathrm{bc}}$ \\
P120-4 & $19.01 \pm 1.37^{\mathrm{g}}$ & $9.62 \pm 0.94^{\mathrm{h}}$ & $29.65 \pm 1.49^{\mathrm{g}}$ & $24.64 \pm 0.78^{\mathrm{g}}$ \\
\hline
\end{tabular}


than those of He plasma (Fig. 2) which may result from the higher amount of produced $\mathrm{NO}$ in $\mathrm{N}$-plasma compared with He-plasma. Some reactive species in the cold plasma-produced gas phase are $\mathrm{NO}, \mathrm{H}_{2} \mathrm{O}_{2}$, superoxide, singlet oxygen, electrons, and positive ions (Bußler et al. 2015b). The modifications in root system recorded in the present study could be attributed to the various active nitrogen and oxygen species, especially $\mathrm{O}_{3}$ and NO produced during plasma treatments. It has been stated that NO can influence root system through two main events: cell division in meristematic zone and cell differentiation (Fernández-Marcos et al. 2011). The decreases in primary root growth and promotions in lateral root development caused by NO have been described in various plants, including tomato (Correa-
Aragunde et al. 2004) and Arabidopsis (Méndez-Bravo et al. 2010). On the basis of microscopic analysis of seedling roots in meristematic zone, the primary root meristem was affected by alterations in NO content (Fernández-Marcos et al. 2011). According to their findings, polar auxin transport also may be affected basically via posttranscriptional modification of PIN1 protein involved in auxin transport. So it seems that plasma treatments according to exposure time and number of repetitions may change root system via alterations in hormonal balance (Benjamins and Scheres 2008) and also can increase water uptake into seeds (Stolárik et al. 2015). But it should be mentioned that more investigations are needed to reveal this effects conclusively. In addition, plasma treatment of wheat
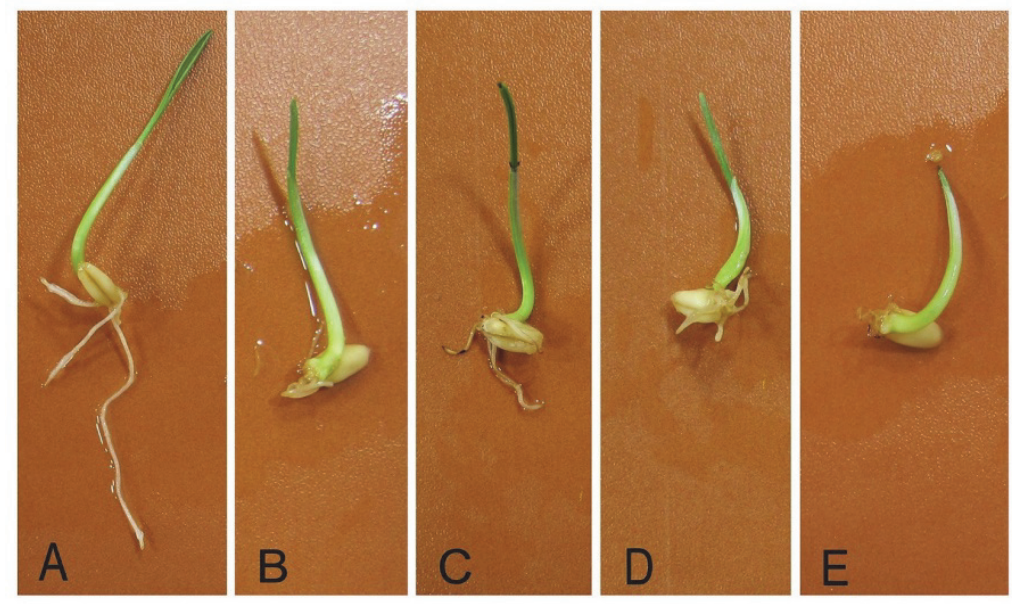

Fig. 2. The impact of some treatments of He or $\mathrm{N}$ derived cold plasma on the growth of 5 -d-old seedlings ( $1 \mathrm{~d}$ after the last plasma treatments): $A$ - control; $B$ - He plasma for $60 \mathrm{~s}$, 4-times; $C$ - N plasma for $60 \mathrm{~s}$, 4-times; $D$ - He plasma for $120 \mathrm{~s}$, 4-times; $E-\mathrm{N}$ plasma for $120 \mathrm{~s}$, 4-times. Rectangles $68 \times 35 \mathrm{~mm}$.

Table 2. Effects of $\mathrm{He}$ or $\mathrm{N}$ derived cold plasma used for different times and repetitions on protein content and activities of peroxidase and phenylalanine ammonia lyase (PAL) in 5-d old wheat seedlings (one day after the last treatments). C - control, P15-1 - plasma $15 \mathrm{~s}$ once, P30-1 - plasma $30 \mathrm{~s}$ once, etc. ... P120-4 - plasma $120 \mathrm{~s}$ four times. Means $\pm \mathrm{SE}, n=4$; values followed by different letters are significantly different at $P \leq 0.05$ according to Duncan's multiple range test.

\begin{tabular}{|c|c|c|c|c|c|c|}
\hline \multirow{2}{*}{$\begin{array}{l}\text { Parameters } \\
\text { Treatments }\end{array}$} & \multicolumn{2}{|c|}{ Protein content $\left[\mathrm{mg} \mathrm{g}^{-1}\right.$ (f.m.)] } & \multicolumn{2}{|c|}{ Peroxidase $\left[\Delta \mathrm{A} \mathrm{g}^{-1}\right.$ (f.m.) $\left.\min ^{-1}\right]$} & \multicolumn{2}{|c|}{ PAL $\left[\mu \mathrm{g}\right.$ (cinnamate) $\mathrm{g}^{-1}$ (f.m.) $\left.\min ^{-1}\right]$} \\
\hline & $\mathrm{He}$ & $\mathrm{N}$ & $\mathrm{He}$ & $\mathrm{N}$ & $\mathrm{He}$ & $\mathrm{N}$ \\
\hline $\mathrm{C}$ & $2.49 \pm 0.05^{\mathrm{h}}$ & $2.49 \pm 0.05^{\mathrm{f}}$ & $44.09 \pm 2.19^{\mathrm{fg}}$ & $44.09 \pm 2.19^{\mathrm{e}}$ & $2.41 \pm 0.04^{\mathrm{e}}$ & $2.41 \pm 0.04^{\mathrm{e}}$ \\
\hline P15-1 & $2.52 \pm 0.02^{\mathrm{gh}}$ & $2.54 \pm 0.04^{\mathrm{f}}$ & $43.13 \pm 1.87^{\mathrm{fg}}$ & $44.35 \pm 1.88^{\mathrm{e}}$ & $2.38 \pm 0.03^{\mathrm{e}}$ & $2.45 \pm 0.04^{\mathrm{e}}$ \\
\hline $\mathrm{P} 15-2$ & $2.54 \pm 0.03^{\mathrm{gh}}$ & $2.65 \pm 0.02^{\mathrm{e}}$ & $48.52 \pm 1.45^{\mathrm{ef}}$ & $47.44 \pm 1.62^{\mathrm{e}}$ & $2.45 \pm 0.01^{\mathrm{e}}$ & $2.69 \pm 0.03^{\mathrm{cd}}$ \\
\hline P15-4 & $2.69 \pm 0.02^{\mathrm{ef}}$ & $2.71 \pm 0.01^{\mathrm{de}}$ & $40.57 \pm 2.93^{\mathrm{g}}$ & $47.37 \pm 0.76^{\mathrm{e}}$ & $2.54 \pm 0.02^{\mathrm{d}}$ & $2.80 \pm 0.01^{\mathrm{b}}$ \\
\hline P30-1 & $2.61 \pm 0.02^{\text {fg }}$ & $2.71 \pm 0.01^{\mathrm{de}}$ & $42.82 \pm 1.75^{\mathrm{fg}}$ & $45.48 \pm 1.29^{\mathrm{e}}$ & $2.59 \pm 0.01^{\mathrm{d}}$ & $2.74 \pm 0.03^{\mathrm{bc}}$ \\
\hline P30-2 & $2.71 \pm 0.01^{\mathrm{de}}$ & $2.79 \pm 0.02^{\mathrm{cd}}$ & $53.97 \pm 1.67^{\text {cde }}$ & $54.48 \pm .83^{\mathrm{cd}}$ & $2.54 \pm 0.02^{\mathrm{d}}$ & $2.87 \pm 0.03^{\mathrm{a}}$ \\
\hline P30-4 & $2.82 \pm 0.02^{\mathrm{c}}$ & $2.91 \pm 0.02^{\mathrm{b}}$ & $50.80 \pm 0.60^{\mathrm{de}}$ & $59.33 \pm 0.98^{\mathrm{bc}}$ & $2.69 \pm 0.02^{\mathrm{c}}$ & $2.76 \pm 0.02^{\mathrm{bc}}$ \\
\hline P60-1 & $2.76 \pm 0.02^{\text {cde }}$ & $2.83 \pm 0.02^{\mathrm{bc}}$ & $51.36 \pm 1.07^{\mathrm{de}}$ & $55.67 \pm 0.64^{\mathrm{cd}}$ & $2.79 \pm 0.01^{\mathrm{ab}}$ & $2.79 \pm 0.02^{\mathrm{b}}$ \\
\hline P60-2 & $2.94 \pm 0.03^{\mathrm{b}}$ & $2.90 \pm 0.04^{\mathrm{b}}$ & $56.72 \pm 1.21^{\mathrm{bcd}}$ & $61.04 \pm 0.44^{\mathrm{ab}}$ & $2.83 \pm 0.02^{\mathrm{ab}}$ & $2.90 \pm 0.01^{\mathrm{a}}$ \\
\hline P60-4 & $3.01 \pm 0.01^{\mathrm{ab}}$ & $3.02 \pm 0.06^{\mathrm{a}}$ & $60.14 \pm 2.35^{\mathrm{b}}$ & $65.17 \pm 2.06^{\mathrm{a}}$ & $2.82 \pm 0.01^{\mathrm{a}}$ & $2.80 \pm 0.02^{\mathrm{b}}$ \\
\hline P120-1 & $2.81 \pm 0.02^{\mathrm{cd}}$ & $2.93 \pm 0.03^{\mathrm{ab}}$ & $52.67 \pm 0.67^{\mathrm{de}}$ & $58.71 \pm 3.12^{\mathrm{bc}}$ & $2.75 \pm 0.02^{\mathrm{bc}}$ & $2.91 \pm 0.02^{\mathrm{a}}$ \\
\hline P120-2 & $2.96 \pm 0.01^{\mathrm{b}}$ & $2.91 \pm 0.02^{\mathrm{b}}$ & $59.00 \pm 1.04^{\mathrm{bc}}$ & $55.84 \pm 0.83^{\mathrm{cd}}$ & $2.75 \pm 0.03^{\mathrm{bc}}$ & $2.63 \pm 0.01^{\mathrm{d}}$ \\
\hline P120-4 & $3.11 \pm 0.10^{\mathrm{a}}$ & $2.93 \pm 0.02^{\mathrm{ab}}$ & $67.02 \pm 3.89^{\mathrm{a}}$ & $53.38 \pm 0.46^{\mathrm{d}}$ & $2.71 \pm 0.02^{\mathrm{c}}$ & $2.65 \pm 0.017^{\mathrm{d}}$ \\
\hline
\end{tabular}


seedlings can affect them via UV produced between two dielectrics and this could modify physiological and metabolic processes including hormone equilibrium, especially auxin, cytokinin, and ethylene content, thereby triggering further mechanisms.

Helium or nitrogen derived plasma, especially the latter one, enhanced protein content except for He15-1, He15-2, N15-1 and the most notable increases were recorded in N60-4 and He120-4 treatments (Table 2). In $\mathrm{He}$ or $\mathrm{N}$ plasma treated seedlings, the highest elevations in peroxidase activity was found in N60-4 and He120-4 (Table 2). He plasma treatments significantly increased the PAL activity and higher activities were recorded in 60 and $120 \mathrm{~s}$ treatments than in shorter ones (Table 2). $\mathrm{N}$ plasma treatment was even more effective than $\mathrm{He}$ plasma to stimulate PAL activities and all nitrogen treated samples except N15-1, showed significant elevation in PAL activity (Table 2). The recorded increases in protein content, the activity of peroxidase (one critical antioxidant enzyme), in combination with inductions in the activity of PAL (a key enzyme in phenylpropanoid metabolism), may be regarded as defense-related responses triggered by plasma especially when times and/or repetition were increased. These results are in agreements with findings of Jiang et al. (2014) indicating that plasma treatments induced activities of antioxidant enzymes and PAL activities in tomato plants, thereby improving resistance against the pathogen Ralstonia solanacearum. The recorded reactions could be attributed to the critical signaling molecules produced during plasma treatments, like nitric oxide, known as a signaling compound, and ozone (recognized as a stress factor) as well as UV radiation. Also, the structural changes in cell wall caused by plasma and production of oligosaccharides may trigger some defense-related responses in a cell. Plasma-inherent reactive oxygen species (ROS) such as hydroxyl radicals and singlet oxygen are present in the plasma and can react with phenolic compounds and cause structural alterations in plants (Grzegorzewski et al. 2011). NO reacts with numerous extracellular/intracellular targets as a free radical and form various reactive nitrogen species (Gross et al. 2013). It is known as a down-regulating signal for hydrogen peroxide, and also as an inducer of ROS degradation and production, thereby targeting the regulatory feed-back complex between signaling molecules (Hasanuzzaman et al. 2012). NO arrests lipid peroxidative reactions and activates expression of antioxidant enzyme genes and this is why it is called a chain-breaking antioxidant (Siddiqui et al. 2011). NO induces cytoprotective proteins and the synthesis of catalase, superoxide dismutase, and glutathione S-transferase (Wang et al. 2013). NO as a signaling compound has a critical role in promoting resistance to salt stress, mainly via the activation of antioxidant defense system, production of osmolytes, special proteins, and so regulates water flux and ion homeostasis (Farooq et al. 2013). In addition, $\mathrm{O}_{3}$ as a strong oxidant can interact with apoplast constituents, and produces reactive oxygen species such as $\mathrm{H}_{2} \mathrm{O}_{2}, \mathrm{OH}^{*}, \mathrm{O}_{2}{ }^{*}$ and HOO $^{\circ}$ (Torsethaugen et al. 1997). The alterations in enzymatic (Labanowska et al. 2016) and non-enzymatic antioxidants (Corpas et al. 2011) due to $\mathrm{O}_{3}$ have been recorded. Therefore, plasma affected metabolism and triggered defense-related reactions could be attributed to the modified redox signal status caused by the plasmaderived signaling molecules. Moreover, as it has been stated that UV exposure strongly stimulates nitric oxide synthase activity (Filatova et al. 2011), the emitted UV during plasma formation may act as an accelerating factor influencing plant physiology. Alterations in the activities of antioxidant enzymes in plants after exposure

Table 3. Effects of He or $\mathrm{N}$ derived cold plasma used for different times and repetitions on shoot and leaf fresh mass and total content of soluble phenols in 35-d-old wheat seedlings ( $30 \mathrm{~d}$ after the last treatment). C - control, P15-1 - plasma $15 \mathrm{~s}$ once, P30-1 - plasma $30 \mathrm{~s}$ once, etc. .... P120-4 - plasma $120 \mathrm{~s}$ four times. Means \pm SEs, $n=4$; values followed by different letters are significantly different at $P \leq 0.05$ according to Duncan's multiple range test. $* *$ - plants were destroyed by plasma treatment.

\begin{tabular}{|c|c|c|c|c|c|c|}
\hline \multirow{2}{*}{$\begin{array}{l}\text { Parameters } \\
\text { Treatments }\end{array}$} & \multicolumn{2}{|c|}{ Shoot fresh mass $[\mathrm{g}]$} & \multicolumn{2}{|c|}{ Leaf fresh mass $[\mathrm{g}]$} & \multicolumn{2}{|c|}{ Soluble phenols [mg g ${ }^{-1}$ (f.m.)] } \\
\hline & $\mathrm{He}$ & $\mathrm{N}$ & $\mathrm{He}$ & $\mathrm{N}$ & $\mathrm{He}$ & $\mathrm{N}$ \\
\hline $\mathrm{C}$ & $0.26 \pm 0.007^{\mathrm{cd}}$ & $0.26 \pm 0.007^{\mathrm{e}}$ & $0.06 \pm 0.002^{\mathrm{de}}$ & $0.06 \pm 0.002^{\mathrm{c}}$ & $3.41 \pm 0.07^{\mathrm{f}}$ & $3.41 \pm 0.07^{\mathrm{c}}$ \\
\hline P15-1 & $0.25 \pm 0.007^{\mathrm{de}}$ & $0.26 \pm 0.004^{\mathrm{e}}$ & $0.07 \pm 0.00^{\mathrm{de}}$ & $0.06 \pm 0.002^{\mathrm{c}}$ & $3.44 \pm 0.03^{\mathrm{ef}}$ & $3.46 \pm 0.06^{\mathrm{c}}$ \\
\hline P15-2 & $0.26 \pm 0.008^{\mathrm{cd}}$ & $0.27 \pm 0.007^{\mathrm{e}}$ & $0.07 \pm 0.002^{\text {cde }}$ & $0.07 \pm 0.002^{\mathrm{bc}}$ & $3.45 \pm 0.03^{\text {ef }}$ & $3.45 \pm 0.08^{\mathrm{c}}$ \\
\hline P15-4 & $0.24 \pm 0.004^{\mathrm{de}}$ & $0.26 \pm 0.007^{\mathrm{e}}$ & $0.06 \pm 0.002^{\mathrm{e}}$ & $0.07 \pm 0.002^{\mathrm{bc}}$ & $3.44 \pm 0.05^{\mathrm{ef}}$ & $3.84 \pm 0.02^{\mathrm{ab}}$ \\
\hline P30-1 & $0.30 \pm 0.002^{\mathrm{b}}$ & $0.27 \pm 0.006^{\mathrm{e}}$ & $0.07 \pm 0.00^{\mathrm{de}}$ & $0.07 \pm 0.002^{\mathrm{abc}}$ & $3.48 \pm 0.02^{\mathrm{def}}$ & $3.46 \pm 0.06^{\mathrm{c}}$ \\
\hline P30-2 & $0.34 \pm 0.006^{\mathrm{a}}$ & $0.36 \pm 0.006^{\mathrm{b}}$ & $0.08 \pm 0.003^{\mathrm{ab}}$ & $0.09 \pm 0.003^{\mathrm{a}}$ & $3.53 \pm 0.03^{\mathrm{de}}$ & $3.83 \pm 0.03^{\mathrm{b}}$ \\
\hline P30-4 & $0.24 \pm 0.01^{\mathrm{e}}$ & $0.30 \pm 0.002^{\mathrm{d}}$ & $0.06 \pm 0.003^{\mathrm{e}}$ & $0.07 \pm 0.003^{\mathrm{abc}}$ & $3.63 \pm 0.02^{\mathrm{bc}}$ & $3.98 \pm 0.03^{\mathrm{a}}$ \\
\hline P60-1 & $0.31 \pm 0.006^{\mathrm{b}}$ & $0.30 \pm 0.003^{\mathrm{d}}$ & $0.08 \pm 0.00^{\mathrm{bc}}$ & $0.07 \pm 0.003^{\mathrm{abc}}$ & $3.55 \pm 0.02^{\mathrm{cd}}$ & $3.95 \pm 0.05^{\mathrm{a}}$ \\
\hline P60-2 & $0.28 \pm 0.010^{\mathrm{c}}$ & $0.32 \pm 0.006^{\mathrm{c}}$ & $0.07 \pm 0.002^{\text {cde }}$ & $0.09 \pm 0.002^{\mathrm{ab}}$ & $3.71 \pm 0.02^{\mathrm{b}}$ & $3.80 \pm 0.02^{\mathrm{b}}$ \\
\hline P60-4 & $0.25 \pm 0.006^{\mathrm{de}}$ & $0.29 \pm 0.004^{\mathrm{d}}$ & $0.06 \pm 0.002^{\mathrm{e}}$ & $0.08 \pm 0.00^{\mathrm{abc}}$ & $3.81 \pm 0.02^{\mathrm{a}}$ & $3.92 \pm 0.02^{\mathrm{ab}}$ \\
\hline P120-1 & $0.32 \pm 0.005^{\mathrm{b}}$ & $0.29 \pm 0.004^{\mathrm{d}}$ & $0.08 \pm 0.002^{\mathrm{a}}$ & $0.08 \pm 0.003^{\mathrm{abc}}$ & $3.65 \pm 0.01^{\mathrm{b}}$ & $3.82 \pm 0.01^{\mathrm{b}}$ \\
\hline P120-2 & $0.28 \pm 0.006^{\mathrm{c}}$ & $0.38 \pm 0.007^{\mathrm{a}}$ & $0.07 \pm 0.002^{\mathrm{cd}}$ & $0.07 \pm 0.02^{\mathrm{abc}}$ & $3.82 \pm 0.01^{\mathrm{a}}$ & $3.87 \pm 0.02^{\mathrm{ab}}$ \\
\hline P120-4 & $0.23 \pm 0.009^{\mathrm{e}}$ & $0.00 \pm 0.00^{\mathrm{f}^{* *}}$ & $0.07 \pm 0.002^{\text {cde }}$ & $0.00 \pm 0.00^{\mathrm{d}^{* *}}$ & $3.90 \pm 0.02^{\mathrm{a}}$ & $0.00 \pm 0.00^{\mathrm{d}^{* *}}$ \\
\hline
\end{tabular}


to UV have been observed in various plant species, such as Populus spp. (Jia et al. 2009), Acorus calamus (Kumari et al. 2010), Corallina officinalis (Li et al. 2010) and Vitis vinifera (Martínez-Lüscher et al. 2013). Therefore, plasma treatments provide a complicated and multiple treatments of signaling molecules and UV, thereby triggering modifications in plant metabolism.

In the long-term assessments of plasma impacts N120-4 was perished, probably because of plasma related tensions. According to our results, in contrast to He120-4, N120-4 manifested a reduced growth in short term period and led to seedling death one week just after planting. Surprisingly, the reducing and inhibitory impacts of extensive plasma treatments, not only mitigated one month after the treatments and caught up control, but also accelerated the growth rate and biomass accumulations in shoot and leaves (Table 3). One month after plasma treatments, increase in shoot fresh mass was recorded in some plasma treatments among which He30-2, He60-1, He120-1, N120-2, N30-2, and N60-2 was the highest. Some plasma treatments led to significantly higher leaf fresh mass where the highest values were observed in N30-2, N60-2, N60-4, N120-1, N120-2, He120-1, He60-1, and He30-2 (Table 3). These findings might be attributed to the possible plasma-induced enhancement in uptake of essential mineral nutrients, modified hormonal balances, or changes in source-sink relations. There is evidence indicating that plasma treatments improve uptake of calcium and boron in tomato, compared to control (Jiang et al. 2014).

The total soluble phenol content increased meaningfully in He30-4, He60, and He120-related treatments, and the highest recorded amount was at He120-4 (Table 3). Except N15-1, N15-2, and N30-1 other applied treatments led to significantly higher content of soluble phenols, comparing with control (Table 3). The obtained results reflect the increases in the content of total soluble phenolic compounds as a longterm consequence of plasma treatment, most probably due to triggering impacts of plasma derived elicitors and/or plasma generated UV. The application of cold plasma technology may be regarded as a suitable approach for modification of valuable secondary plant metabolites (Bußler et al. 2015a). Fan et al. (2014) and Ibrahim and Srour (2015) demonstrate that elevating UV-B irradiation can lead to the flavonoid synthesis rise via stimulating PAL activity in soybean seedlings.

In conclusion, it seems that plasma treatments might have significant desirable promoting effects on plant growth and physiology probably via stimulating defenserelated metabolism, influencing plant nutrition, and modifying hormonal balances. More precise investigations are needed to reveal the exact physiological and molecular mechanisms involved in these processes. Cold atmospheric plasma technology may be considered as an alternative approach to provide conditions in which plant is subjected to combined treatments of several biochemical- and photo-elicitors, thereby triggering modifications of metabolism. Data about plant-plasma interactions are rare and incomplete, so this article could be path stimulating research in this progressing field.

\section{References}

Alekseev, O., Donovan, K., Limonnik, V. Azizkhan-Clifford, J.: Nonthermal dielectric barrier discharge (DBD) plasma suppresses herpes simplex virus type 1 (HSV-1) replication in corneal epithelium. - Trans. Visual. Sci. Technol. 3: 1-14, 2014.

Beaudoin-Eagan, L.D., Thorpe, T.A.: Tyrosine and phenylalanine ammonia lyase activities during shoot initiation in tobacco callus cultures. - Plant Physiol. 78: 438441, 1985.

Benjamins, R., Scheres, B.: Auxin: the looping star in plant development. - Annu. Rev. Plant Biol. 59: 443-465, 2008.

Biles, C.L., Abeles, F.B.: Xylem sap proteins. - Plant Physiol. 96: 597-601, 1991.

Bradford, M. M.: A rapid and sensitive method for the quantitation of microgram quantities of protein utilizing the principle of protein-dye binding. - Anal. Biochem. 72: 248254, 1976.

Bußler, S., Herppich, W.B., Neugart, S., Schreiner, M., Ehlbeck, J., Rohn, S., Schlüter, O.: Impact of cold atmospheric pressure plasma on physiology and flavonol glycoside profile of peas (Pisum sativum 'Salamanca'). Food Res. Int. 76: 132-141, 2015a.

Bußler, S., Steins, V., Ehlbeck, J., Schlüter, O.: Impact of thermal treatment versus cold atmospheric plasma processing on the techno-functional protein properties from Pisum sativum 'Salamanca'. - J. Food Eng. 167: 166-174,

\section{5b.}

Chen, H.H., Chen, Y.K., Chang, H.C.: Evaluation of physicochemical properties of plasma treated brown rice. Food Chem. 135: 74-79, 2012.

Corpas, F.J., Leterrier, M., Valderrama, R., Airaki, M., Chaki, M., Palma, J.M., Barroso, J.B.: Nitric oxide imbalance provokes a nitrosative response in plants under abiotic stress. - Plant Sci. 181: 604-611, 2011.

Correa-Aragunde, N., Graziano, M., Lamattina, L.: Nitric oxide plays a central role in determining lateral root development in tomato. - Planta 218: 900-905, 2004.

Domingos, P., Prado, A.M., Wong, A., Gehring, C., Feijo, J.A.: Nitric oxide: a multitasked signaling gas in plants. - Mol. Plant. 8: 506-520, 2015.

Fan, C., Hu, H., Wang, L., Zhou, Q., Huang, X.: Enzymological mechanism for the regulation of lanthanum chloride on flavonoid synthesis of soybean seedlings under enhanced ultraviolet-B radiation. - Environ. Sci. Pollut. Res. 21: 87928800, 2014.

Farooq, M., Siddique, K.H., Schubert, S.: Role of nitric oxide in improving plant resistance against salt stress. - In: Ahmad, P. (ed.): Ecophysiology and Responses of Plants under Salt Stress. Pp. 413-424. Springer, Dordrecht 2013.

Fernández-Marcos, M., Sanz, L., Lewis, D.R., Muday, G.K., Lorenzo, O.: Nitric oxide causes root apical meristem defects and growth inhibition while reducing PIN- 
FORMED 1 (PIN1)-dependent acropetal auxin transport. Proc. nat. Acad. Sci. USA 108: 18506-18511, 2011.

Filatova, I., Azharonok, V., Kadyrov, M., Beljavsky, V., Gvozdov, A., Shik, A., Antonuk, A.: The effect of plasma treatment of seeds of some grains and legumes on their sowing quality and productivity. - Rom. J. Phys. 56: 139143, 2011.

Fridman, A.: Plasma Chemistry. - Cambridge University Press, Cambridge 2008

Goldwasser, Y., Hershenhorn, J., Plakhine, D., Kleifeld, Y., Rubin, B.: Biochemical factors involved in vetch resistance to Orobanche aegyptiaca. - Physiol. mol. Plant Pathol. 54: 87-96, 1999.

Groß, F., Durner, J., Gaupels, F.: Nitric oxide, antioxidants and prooxidants in plant defence responses. - Front. Plant Sci. 4: 419, 2013.

Grzegorzewski, F., Ehlbeck, J., Schlüter, O., Kroh, L.W., Rohn, S.: Treating lamb's lettuce with a cold plasma - influence of atmospheric pressure Ar plasma immanent species on the phenolic profile of Valerianella locusta. - LWT-Food Sci. Technol. 44: 2285-2289, 2011.

Hasanuzzaman, M., Hossain, M.A., Da Silva, J.A.T., Fujita, M.: Plant response and tolerance to abiotic oxidative stress: antioxidant defense is a key factor. - In: Venkateswarlu, B. (ed.): Crop Stress and Its Management: Perspectives and Strategies. P. 261-315. Springer, Dordrecht 2012.

Ibrahim, M., Srour, H.: Effect of solar UV radiation on antioxidant enzymes and phenols biosynthesis in lettuce (Lactuca sativa). - Arab. Univ. J. agr. Sci. 23: 101-108, 2015.

Jia, X., Ren, L., Chen, Q. J., Li, R., Tang, G.: UV-B-responsive microRNAs in Populus tremula. - J. Plant Physiol. 166: 2046-2057, 2009

Jiang, J., Lu, Y., Li, J., Li, L., He, X., Shao, H., Dong, Y.: Effect of seed treatment by cold plasma on the resistance of tomato to Ralstonia solanacearum (bacterial wilt). - Plos ONE 9: e97753, 2014.

Kashyap, P., Sehrawat, A., Deswal, R.: Nitric oxide modulates Lycopersicon esculentum C-repeat binding factor 1 (LeCBF1) transcriptionally as well as post-translationally by nitrosylation. - Plant Physiol. Biochem. 96: 115-123, 2015.

Kumari, R., Singh, S., Agrawal, S.: Response of ultraviolet-B induced antioxidant defense system in a medicinal plant, Acorus calamus. - J. environ. Biol. 31: 907-911, 2010.

Łabanowska, M., Kurdziel, M., Filek, M.: Changes of paramagnetic species in cereal grains upon short-term ozone action as a marker of oxidative stress tolerance. - J. Plant Physiol. 190: 54-66, 2016.

Lamattina, L., Polacco, J.C.: Nitric Oxide in Plant Growth, Development and Stress Physiology. - Springer Science \& Business Media, Nuremburg 2007.

Li, L., Zhao, J., Tang, X.: Ultraviolet irradiation induced oxidative stress and response of antioxidant system in an intertidal macroalgae Corallina officinalis L. - J. environ. Sci. 22: 716-722, 2010.

Ling, L., Jiafeng, J., Jiangang, L., Minchong, S., Xin, H., Hanliang, S., Yuanhua, D.: Effects of cold plasma treatment on seed germination and seedling growth of soybean. - Sci. Rep. 4: 112-116, 2014.

Louste, C., Artana, G., Moreau, E., Touchard, G.: Sliding discharge in air at atmospheric pressure: electrical properties. - J. Electrostatics. 63: 615-620, 2005.

Martínez-Lüscher, J., Morales, F., Delrot, S., Sánchez-Díaz, M., Gomès, E., Aguirreolea, J., Pascual, I.: Short-and long-term physiological responses of grapevine leaves to UV-B radiation. - Plant Sci. 213: 114-122, 2013.

Méndez-Bravo, A., Raya-González, J., Herrera-Estrella, L., López-Bucio, J.: Nitric oxide is involved in alkamideinduced lateral root development in Arabidopsis. - Plant Cell Physiol. 51: 1612-1626, 2010.

Mihai, A., Dobrin, D., Magurenau, M., Popa M.: Positive effect of non-thermal plasma treatment in radish seeds. - Rom. Rep. Phys. 66: 1110-1117, 2014.

Mitra, A., Li, Y.F., Klämpfl, T.G., Shimizu, T., Jeon, J., Morfill, G.E., Zimmermann, J.L.: Inactivation of surfaceborne microorganisms and increased germination of seed specimen by cold atmospheric plasma. - Food Bioproces. Technol. 7: 645-653, 2014.

Park, D.P., Davis, K., Gilani, S., Alonzo, C-A., Dobrynin, D., Friedman, G., Fridman, A., Rabinovich, A., Fridman, G.: Reactive nitrogen species produced in water by nonequilibrium plasma increase plant growth rate and nutritional yield. - Curr. appl. Phys. 13: S19-S29, 2013.

Santisree, P., Bhatnagar-Mathur, P., Sharma, K.K.: NO to drought - multifunctional role of nitric oxide in plant drought: do we have all the answers?. - Plant Sci. 239: 44$55,2015$.

Sera, B., Spatenka, P., Sery, M., Vrchotova, N., Hruskova, I.: Influence of plasma treatment on wheat and oat germination and early growth. - IEEE Trans. Plasma Sci. 38: 2963-2968, 2010.

Será, B., Stranák, V., Serý, M., Tichý, M., Spatenka, P.: Germination of Chenopodium album in response to microwave plasma treatment. - Plasma Sci. Technol. 10: 506, 2008.

Shi, J., Kong, M.G.: Mechanisms of the $\alpha$ and $\gamma$ modes in radiofrequency atmospheric glow discharges. - J. appl. Phys. 97: 023306, 2005.

Siddiqui, M.H., Al-Whaibi, M.H., Basalah, M.O.: Interactive effect of calcium and gibberellin on nickel tolerance in relation to antioxidant systems in Triticum aestivum L. Protoplasma 248: 503-511, 2011.

Stolárik, T., Henselová, M., Martinka, M., Novák, O., Zahoranová, A., Černák, M.: Effect of low-temperature plasma on the structure of seeds, growth and metabolism of endogenous phytohormones in pea (Pisum sativum L.). Plasma Chem. Plasma Proc. 35: 659-676, 2015.

Torsethaugen, G., Pitcher, L.H., Zilinskas, B.A., Pell, E.J.: Overproduction of ascorbate peroxidase in the tobacco chloroplast does not provide protection against ozone. Plant Physiol. 114: 529-537, 1997.

Wang, Y., Loake, G.J,. Chu, C.: Cross-talk of nitric oxide and reactive oxygen species in plant programed cell death. Front. Plant Sci. 4: 314, 2013.

Welch, R.M., Graham, R.D.: Breeding for micronutrients in staple food crops from a human nutrition perspective. - J. exp. Bot. 55: 353-364, 2004

Wu, Z., Chi, L., Bian, S., Xu, K.: Effects of plasma treatment on maize seedling resistance. - J. Maize Sci. 15: 111-113, 2007. 